\title{
The Application on Teacher Discipline to Improve Teacher Performance; a Review
}

\author{
Eko Henny Setyowati \\ \{ekohennysetyowati@gmail.com\} \\ Faculty of Teaching and Education, Universitas Muria Kudus Gondang Manis PO. BOX 53 Bae, \\ Kudus, Central Java, Indonesia Phone (+62291) 438229, Fax (+62291)437198
}

\begin{abstract}
Teacher discipline is an important aspect that must be possessed by professional educators. A disciplined attitude needs to be held to improve teacher performance. This paper will focus on teacher discipline of teachers to improve teacher performance based on the performance standards of teacher evaluation. Discipline attitudes and behaviors in daily life that are carried out consistently by teachers inside and outside of learning tend to imitate by their student so that discipline can be transmitted to students. Self-discipline on teachers" attitude also leads to teacher performance. The discipline in planning, implementing, and evaluating of learning process directly can be formed in carrying out the duties and responsibilities of the teacher as a professional educator.
\end{abstract}

Keywords: the discipline of teachers, teachers‘ performance

\section{Introduction}

Teacher discipline is one of several complex discipline problems in schools. Besides, the discipline at school also includes student discipline [1], classroom discipline [2], and school discipline [3]. All of these disciplines are the main pillars of school culture. The teacher as an educator has an important role in educating students. The teacher becomes a role model that is often imitated by students, so the teacher should set a good example. One of the behaviors that can be an example for students is the attitude of the teacher who is always motivated and disciplined. Enforcement of discipline is very important to achieve an effective and efficient learning process. A disciplined teacher can guarantee the maintenance of school rules and the smooth implementation of school management. Therefore, teacher discipline requires a teacher's commitment that is full of loyalty and obedience to regulations and is aware of his responsibility to carry out the school's goals [4] [5].

The teacher discipline has received less attention so far, the main topic of discipline in schools is how to discipline the students [6]. Also, the standard of teacher discipline is still using "old-school" indicators, such as arriving on time, complying with school rules, and maintaining their behavior in front of students [7]. Such disciplinary perceptions are not wrong at all. Morally, discipline is indeed shown through the attitudes and behavior since the teacher is the role model for students [8]. However, those concepts of discipline are considered less able to contribute to improvement in teacher performance.

Teacher performance in a school plays a role in successfully achieving school goals [5]. Teacher performance standards are the basis of all actions to be carried out by teachers, with the main purpose of the development of the teacher as professional educators [9]. Teacher performance standards are summarized in an evaluation called Teacher Performance 
Assessment (Penilaian Kinerja Guru/PKG). Competencies covered in aspects of PKG are used to evaluate teacher performance so that they can carry out the learning process to the maximum. In addition, $\mathrm{PKG}$ is also intended to determine the progress of teachers in developing themselves and learning [10].

This paper will focus on teacher discipline of teachers to improve teacher performance based on the performance standards of teacher evaluation. This paper will proceed as follows: first, we will give a short summary of some relevant literature. Then, we discuss how the discipline of a teacher can improve teacher performance. Finally, we will construct a proposed discipline model that is practical and essential for teachers to apply to improve their performance.

\section{Literature Perspective}

\subsection{Teacher Discipline}

Discipline simply means the ability to control yourself or other people, even in difficult situations. Discipline can also be interpreted as training that makes people more willing to obey or more able to control themselves, often in the form of rules, and punishments if these are broken, or the behavior produced by this training. Discipline refers fundamentally to the principle that each organism learns to some degree to control itself to conform to the forces around it which it has experienced [4].

Practically, discipline is an action that is regulated to be in accordance (or to achieve accord) with a particular system of governance. Discipline is always oriented to the rules, norms or limits of behavior that have been set [11]. Discipline is compliance or obedience in complying with regulations or norms that apply in certain environments. The forms of discipline that can be applied by teachers in carrying out their duties are reflected in the attitudes and behavior of teachers in planning learning, implementing learning, and evaluating learning [12]. Those steps are in line with the evaluation of the technical components in PKG instruments: Learning Implementation Plan (Rencana Pelaksanaan Pembelajaran/RPP), learning procedures, and evaluation/assessment of learning.

In the context of schools, the norms that must be obeyed are the regulations relating to National Education Policies to the school code of conduct. Discipline is one of the factors supporting the success of teachers in achieving the planned objectives in the learning process activities. With high work discipline, a teacher can be an example to students and colleagues [12]. Work discipline is known to influence efficiency and effectiveness. A teacher who applies high work discipline does their work as efficiently and effectively as possible [11].

The purpose of discipline is to make someone trained, controlled, by teaching them forms of behavior that are appropriate and inappropriate or that are still unfamiliar to them. Thus, discipline will lead to self-control or control of one's behavior based on the norms and rules that apply because they feel the norms and rules have become their own [4].

Discipline in the management of an organization is divided into 2 types [13], namely:

a. Self-discipline, which is the attitude of discipline that arises because a person feels fulfilled his needs and has become part of the organization so that the person will be moved to realize and voluntarily comply with all applicable regulations.

b. Command discipline, a disciplined attitude that arises because of coercion/threats from others. This type of discipline is, in fact, more often found in the implementation of an organization or institution. 


\subsection{Teacher Performance}

The main task of a teacher as an educator in a school is to channel information in the form of knowledge that is used as provisions by students to be able to attend education to the next level [9]. The teacher's actions in carrying out the given tasks can be called teacher performance. In detail, teacher performance can be defined as work results achieved by the teacher in to achieve educational goals based on standardization or size and time that are tailored to the type of work and under established ethical norms [5].

A teacher must understand the complexity of the National Education System and the impact of applying every measure of policy to the whole system in the context of the dynamics and evolution of the education system. Therefore, teachers need to always update their knowledge and improve their performance [14].

Teacher performance can be shown from the competencies that are required to be fulfilled, namely those competencies include pedagogical competencies, personal competencies, social competencies, and professional competencies according to the regulation of academic qualification standards and teacher competencies (Peraturan Menteri Pendidikan Nasional Republik Indonesia Nomor 16 Tahun 2007 tentang Standar Kualifikasi Akademik dan Kompetensi Guru).

\section{Discussion}

\subsection{Improving Teacher Performance through Teacher Discipline}

Discipline is very important in all educational institutions because it trains individuals to develop responsible behavior that leads to a disciplined person [15]. Teacher discipline forms individuals who are responsible for their duties as educators as well as school managers. As educators, teachers will be able to control themselves and be able to keep the rules well. the attitude of discipline carried out in learning activities will facilitate teachers to carry out effective teaching. The intended learning activities start from planning, implementation, to learning assessment. The structured process will make learning activities effective. Effective learning is known to be in line with increasing student learning achievement [16].

Teacher discipline in fulfilling teacher competency standards is also very important. Teachers as professional educators need to be tested for their competence. The competency dimensions regulated by PKG instruments can be fulfilled properly and on time if the teacher can instill discipline in carrying out his profession. Discipline on competencies that need to be met include:

a. Pedagogic competence is the ability to manage student learning. Learning management requires consistent discipline. The administration of very many learning activities often makes teachers reluctant to do it routinely. In fact, routine work can make it easier for teachers to follow the development of learning and evaluate the shortcomings and problems that arise as soon as possible [17] [18].

b. Personality competence is a personal ability that is steady, noble, wise, authoritative, and be an example of students. The disciplined personal teacher will bring significant changes to the affective students. Teachers who are able to apply self-discipline will not be burdened to show orderly behavior naturally and not made up. This makes the teacher more confident to manage learning activities in the classroom [18].

c. Social competence is the ability of teachers to communicate and interact effectively and efficiently with students, fellow teachers, parents/guardians of students, and surrounding 
communities. The application of teacher discipline can facilitate the fulfillment of social competence, bearing in mind that disciplined teachers will be accustomed to working in a structured manner and can easily explain matters related to the obligations they carry. Thus, the ability of interaction and communication will be helped, in addition to the resulting time efficiency that can be used to share with colleagues [18].

d. Professional competence is the ability to master the subject matter widely and deeply. Mastery of current subject matter and following developing technology can be helped if the teacher always applies a disciplined attitude. Teachers who are actively evaluating the subject matter they teach will have the motivation to update old subject matter to improve the implementation of further learning [17] [18] [19].

In addition, teacher discipline in terms of administration will ease the workload of teachers because the administrative obligations of teachers can be resolved properly and in an orderly manner. This will indirectly be able to save time to work efficiently so that teachers have more time to update information related to learning tasks and carry out activities related to self-development [19]. Teacher self-development mostly sponsored by the government which invested a large amount of budget on teacher learning or teacher professional development. This may lead teachers to improve their ability and also competencies as a professional educator [20].

\section{Conclusion}

This paper discussed the importance of teacher discipline to improve teacher performance. The main role of teachers is producing excellent students with knowledge, skills and of course morals as well. The teaching process and results received by students is very dependent on teacher performance, especially from what is exemplified. Discipline attitudes and behaviors in daily life that are carried out consistently by teachers inside and outside of learning can indirectly affect students' affective. Students tend to imitate their teachers who they consider to be role models so that discipline can be transmitted to students.

On the other hand, self-discipline on teachers' attitude can effect on teacher performance. The discipline in planning, implementing, and evaluating of learning process directly can be formed in carrying out the duties and responsibilities of the teacher as a professional educator. Practically, the teacher discipline that is formed makes it easy for teachers to meet the demands of all teacher performance competencies, namely pedagogical competencies, personal competencies, social competencies, and professional competencies.

As a suggestion, the teacher discipline needs to be developed consistently from the selfconsistently so that it can develop into school culture. On the other hand, aspects of teacher discipline assessment need to be refined. Aspects of assessment such as arriving on time, complying with school rules, and maintaining their behavior in front of students should not be the main standard in the assessment of teacher discipline because it cannot reflect discipline that can improve teacher performance. More basic aspects of teacher discipline assessment such as discipline in planning, implementation, and evaluation of learning can be highlighted because they are directly connected with aspects of teacher competency standards used for teacher performance assessment (PKG).

\section{Acknowledgements}

The author is grateful to the Teacher Training and Education Faculty of Muria Kudus University Indonesia for their academic support. 


\section{References}

[1] Ehiane, O. S.: Discipline and Academic Performance (A Study of Selected Secondary Schools in Lagos, Nigeria). International Journal of Academic Research in Progressive Education and Development, Vol. 3, No. 1. pp. 181-194 (2014)

[2] Lopes, J. and Oliviera, C.: Classroom Discipline: Theory and Practice. In J. P. Bakken (Ed.), Classrooms: Academic Content and Behavior Strategy Instruction for Students With and Without Disabilities. pp. 231-253 (2017)

[3] Zachos, D. T., Delaveridou, A., and Gkontzou, A.: Teachers and School "Discipline" in Greece: A Case Study. European Journal of Social Sciences Education and Research, Vol. 3, No. 3. pp. 8-19 (2016)

[4] Rohman, F.: Peran Pendidik dalam Pembinaan Disiplin Siswa di Sekolah/Madrasah. Jurnal Ihya al-Arabiyah, Vol. 4, No. 1.pp. $72-94$ (2018)

[5] Supardi.: Kinerja Guru. Raja Grafindo. (2013)

[6] Rahimi, M. dan Karkami, F. H.: The role of teachers' classroom discipline in their teaching effectiveness and students' language learning motivation and achievement: A path method. Iranian Journal of Language Teaching Research, Vol. 3, No. 1. pp. 57-82 (2015)

[7] Putri, A. R.: Kedisiplinan Guru dalam Upaya Peningkatan Prestasi Belajar Siswa di SMK Wahyu Makassar. Jurnal Sosialisasi Pendidikan Sosiologi. Vol. 3, No. 1. pp. 1-5. (2016)

[8] Ritonga, A. A. and Irwan.: Tafsir Tarbawi. Citapustaka Media. (2013)

[9] Mulyasa, E.: Standar Kompetensi dan Sertifikasi Guru. Remaja Rosdakarya. (2013)

[10] Madjid, A.: Pengembangan Kinerja Guru Melalui: Kompetensi, Komitmen dan Motivasi Kerja. Samudra Biru. (2016)

[11] Sarwani.: The Effect of Work Discipline and Work Environment on the Performance of Employees. Sinergi. Vol. 6, No. 2. pp. 53-67. (2016)

[12] Maui.: Disiplin Guru dalam Pembelajaran. Jurnal Manajer Pendidikan. Vol. 9, No. 6. pp. 814821. (2015)

[13] Hagang, F. R.: Tinjauan Tentang Pelaksanaan Disiplin Kerja Pegawai pada Dinas Kebersihan dan Pertamanan Kota Samarinda. eJournal Administrasi Negara. Vol. 5, No. 1. pp. 5581-5593. (2017)

[14] de Almeida, J. C.: Teacher Performance Evaluation: The Importance of Performance Standards. International Journal for Cross-Disciplinary Subjects in Education. Vol. 8, No. 1. pp. 2973-2981. (2017)

[15] Onderi, H. L. N. and Odera, F. Y.: Discipline as a tool for effective school management. Educational Research. Vol. 3, No. 9. pp. 710-716. (2012)

[16] Dunlosky, J., Rawson, K. A., Marsh, E. J., NathanM. J., and Willingham, D. T.: Improving Students' Learning With Effective Learning Techniques: Promising Directions From Cognitive and Educational Psychology. Psychological Science in the Public Interest. Vol. 14, No. 1. pp. 458. (2013)

[17] Puspitasari, A., Anugerahwati, M., dan Rachmajanti, S.: Teachers Pedagogical and Professional Competencies in CLIL-Based Primary Schools in Indonesian Context. International Conference on Education Education in the 21st Century: Responding to Current Issues. 105-115. (2016)

[18] Abidin, Z. and Sutrisno.: Analisis Penilaian Kinerja Guru (PKG) dalam Upayanya Melakukan Penjaminan Mutu Guru di dalam Kelas. Research and Development Journal Of Education. Vol. 1, No.01.pp. 16-25. (2014)

[19] Postholm, M. B.: Teachers'professional development: a theoretical review. Educational Research. Vol. 54, No. 4. pp. 405-429. (2012)

[20] Bautista, A. and Ortega-Ruiz, R.: Teacher Professional Development: International Perspectives and Approaches. Psychology, Society, \& Education. Vol. 7, No.3. pp. 240-251. (2015) 